Chicago-Kent College of Law

Scholarly Commons @ IIT Chicago-Kent College of Law

All Faculty Scholarship

Faculty Scholarship

February 2001

\title{
Laidlaw: Redressing the Law of Redressability
}

Harold J. Krent

IIT Chicago-Kent College of Law, hkrent@kentlaw.iit.edu

Follow this and additional works at: https://scholarship.kentlaw.iit.edu/fac_schol

Part of the Courts Commons

\section{Recommended Citation}

Harold J. Krent, Laidlaw: Redressing the Law of Redressability, 12 Duke Envtl. L. \& Pol'y F. 85 (2001). Available at: https://scholarship.kentlaw.iit.edu/fac_schol/332

This Article is brought to you for free and open access by the Faculty Scholarship at Scholarly Commons @ IIT Chicago-Kent College of Law. It has been accepted for inclusion in All Faculty Scholarship by an authorized administrator of Scholarly Commons @ IIT Chicago-Kent College of Law. For more information, please contact jwenger@kentlaw.iit.edu, ebarney@kentlaw.iit.edu. 


\title{
LAIDLAW: REDRESSING THE LAW OF REDRESSABILITY
}

\author{
HAROLD J. KRENT*
}

\section{INTRODUCTION}

Contemporary standing doctrine has revolutionized public interest litigation by requiring not only that the injuries asserted be individuated, but that the remedies sought be capable of redressing those harms. Through standing doctrine, the Court has erected a substantial barrier to citizen oversight of both governmental and nongovernmental conduct.

Although much of standing doctrine protects decision-making by Congress and the executive branch, the Court ironically has more recently used standing doctrine to enhance its own power at the expense of Congress. In Lujan v. Defenders of Wildlife, the Court invalidated a congressional grant of citizen standing under the Endangered Species Act because the congressional enactment failed to require sufficient injury in fact. Subsequently, in Raines $v$. Byrd, ${ }^{2}$ the Court invalidated a congressional grant of standing to members of Congress to challenge the Line Item Veto Act. Although the rhetoric of Lujan and Raines defends standing in terms of preserving a limited judicial role, the reality is that courts have interfered with the majoritarian process by nullifying congressional decisions as to the appropriate parties to vindicate particular rights. The Court has transmuted standing from a means of protecting the majoritarian process into a judicial weapon that can override congressional judgments about the optimal enforcement of particular laws.

Lujan contemplates that courts must independently assess each asserted injury in fact to assure that the injury is substantial or at least individuated enough to satisfy the "case or controversy" require-

* Professor and Associate Dean, Chicago-Kent College of Law. I would like to thank Doug Letter and Dan Tarlock for comments on an earlier draft, and I would like to thank the Duke Environmental Law \& Policy Forum for taking the initiative to host and facilitate the recent conference on Laidlaw.

1. 504 U.S. 555 (1992).

2. 521 U.S. 811 (1997). 
ment. ${ }^{3}$ A congressional creation of a new injury may suffice-such as under the Freedom of Information $\mathrm{Act}^{4}$ or the National Environmental Policy Act ${ }^{5}$-but only if the injury meets the Court's criteria for the injury in fact test. For instance, a congressional determination that all citizens are harmed by pollution is not enough. Congress must limit standing to a group harmed by pollution in a particular way, whether because of increased risk of disease or because of frequent use of affected areas. Courts limit congressional control of access to the courthouse doors.

The Court, however, has not had occasion to determine whether congressional findings or determinations as to redressability-a distinct doctrinal component of standing - should similarly be secondguessed. In contrast to injury in fact, the redressability inquiry is more fact based. Courts must predict the degree to which a favorable judicial decision will remedy the plaintiff's asserted injury. The redressability inquiry also often includes complex forecasting.

This past term's decision in Friends of the Earth, Inc. v. Laidlaw Environmental Services, Inc. ${ }^{7}$ raises the deference issue. In Laidlaw the Court held in a Clean Water Act suit that the plaintiff environmental organization could seek civil penalties payable to the United States Treasury because such relief redressed its continuing interest in being free from illegal discharges in the future. ${ }^{8}$ Central to the Court's conclusion was a premise, based in part on Congress's implicit determination in creating the civil penalty scheme, that any company "in violation" of the Act at the time the complaint was filed likely will repeat such conduct in the future." An award of civil penalties therefore would redress the harm by deterring continued unlawful conduct. Thus, in upholding standing, the Court arguably carved out for Congress a greater role in determining redressability than likely was anticipated after its Lujan decision.

Part I of this Article initially examines the role of congressionally created interests, the violation of which may give rise to standing. $\mathrm{Al}$ though the Court has recognized congressional creation of new interests, the Court in Lujan held that the injuries defined by Congress

\footnotetext{
3. See 504 U.S. at $576-78$.

4. 5 U.S.C. $\$ 552$ (1994 \& Supp. V 1999).

5. 42 U.S.C. $\$ 4321$ (1994).

6. See, e.g., Allen v. Wright, 468 U.S. 737 (1984).

7. 528 U.S. 167 (2000).

8. See id. at 187-189.

9. See id. at 184-186.
} 
must be individuated. ${ }^{10}$ The Court may defer to congressional determination of the adequacy of particular injuries, but not when the injuries are drawn too broadly.

In addition to injury in fact, the Court requires the relief sought to redress the injuries asserted. Otherwise, judicial decisions would resemble advisory opinions. The Court has vacillated in deciding how demanding the redressability inquiry should be. In City of Los Angeles $v$. Lyons ${ }^{11}$ the Court held that a plaintiff who had suffered injuries as a result of a chokehold administered by Los Angeles City Police Department officers could not seek an injunction because the injunction would not help redress any injury in the absence of a showing that plaintiff likely would be subjected to a chokehold in the future. ${ }^{12}$ Similarly, in Steel Company v. Citizens for a Better Environ$m e n t,{ }^{13}$ the Court apparently was of the view that parties can only recover penalties payable to the government if they can demonstrate a substantial continuing risk of harm. The Court's decision in Laidlaw, however, undercuts Lyons and Steel Company by permitting suit even when the prospect that the relief would prevent future harm is highly speculative. The decisions can be accommodated, however, by understanding the pivotal congressional role in determining that particular remedies are likely to redress categories of harm. The Court was willing to defer to Congress's determination that there was a significant risk of recurring harm in Clean Water Act cases while there was no congressional judgment to defer to in Lyons and only an insufficiently considered judgment in Steel Company.

Part II then briefly explores the normative underpinnings of Laidlaw. Accepting for the purpose of this Article the Court's standing doctrine, ${ }^{14}$ deference to Congress comports with a proper understanding of the allocation of authority among the branches. Congress is better equipped than courts to engage in fact-finding. It has the time and resources to assess the remedial issue more fully than the courts. Given Congress's wide latitude in determining which parties should enforce particular laws, courts should defer to explicit and implicit congressional findings that illuminate the link between

10. See Lujan v. Defenders of Wildlife, 504 U.S. 555, 576-78 (1992).

11. 461 U.S. 95 (1983).

12. See id. at 98.

13. 523 U.S. 83 (1998).

14. For my own views on the Court's premise that congressional creation of a right to sue is not sufficient to satisfy Article III's case or controversy requirement, see Harold J. Krent \& Ethan Shenkman, Of Citizen Suits and Citizen Sunstein, 91 MiCH L. REv. 1793 (1993). 
relief and injury. Only in the most extreme cases should the Court second-guess a congressional determination of deterrent impact. Indeed, congressional findings as to redressability help make Congress's enforcement decisions more transparent and accessible to the public as a whole.

Part III then considers the limits that courts should place on Congress's power to ensure redressability. First, courts should review any determination as in Steel Company to convince themselves that the congressional judgment is at least plausible. Second, to ensure that redressability exists in a particular case, courts should allow defendants to show that there is no realistic chance of redressability given the particular circumstances. Despite the deference that should be afforded to congressional determinations in this area, this article concludes by arguing that courts should not find redressability for plaintiffs who can only claim a stake in the litigation-whether because of expectations of a bounty or attorney fee award-unless the award provides either compensation for past injury or sufficient deterrence of repeated wrongdoing to protect plaintiffs from future harm.

\section{I}

The Supreme Court has recognized a wide ambit within which Congress can determine which interests can be vindicated in court. Throughout the nation's first century the Court, often without comment, permitted Congress complete discretion in determining the interests that could be raised in lawsuits. ${ }^{\text {is }}$ In general, restrictive rules of justiciability only began to emerge as a reaction to activist judges striking down legislation in the Lochner era. ${ }^{16}$ The Court never explicitly articulated an independent requirement of an injury in fact until the Warren Court, and then perhaps only as a misguided effort

15. See, e.g., Donald L. Doernberg, "We the People": John Locke, Collective Constitutional Rights, and Standing to Challenge Government Action, 73 CAL. L. REV. 52 (1985); William Fletcher, The Structure of Standing, 98 YALE L.J. 221 (1988); Louis Jaffee, The Citizen as Litigant in Public Actions: The Non-Hohfeldian or Ideological Plaintiff, 116 U. PA. L. REV. 1033 (1968); Gene R. Nichol, Jr., Justice Scalia, Standing and Public Law Litigation, 42 DUKE L.J. 1141 (1993); Cass R. Sunstein, What's Standing After Lujan? Of Citizen Suits, "Injuries," and Article III, 91 MICH. L. REV. 163, 173-78 (1992); Steven Winter, The Metaphor of Standing and the Problem of Self-Governance, 40 STAN. L. REV. 1371 (1988).

16. See, e.g., Massachusetts v. Mellon, 262 U.S. 447 (1923). See also Sunstein, supra note 15, at 179-81; Fletcher, supra note 15, at 225. 
to simplify the legal inquiry into whether a particular plaintiff could sue. ${ }^{17}$

In demanding injuries in fact, the Court stressed that the injury must be direct and palpable. The Court controlled whether the assertion of economic, aesthetic, or environmental harm sufficed. ${ }^{18}$ If the injury were too abstract or generalized, the Court denied standing. ${ }^{19}$

After articulation of the injury in fact test, the Court struggled in determining whether Congress had plenary authority to recognize or create injuries that would satisfy the Court's test. For instance, in Trafficante v. Metropolitan Life Insurance Co. ${ }^{20}$ the Court considered whether a white tenant could sue under a statute permitting anyone to challenge housing discrimination practices. ${ }^{21}$ Congress in essence had created a new interest that safeguarded the opportunity to benefit from "interracial association." permitted the suit to proceed. ${ }^{23}$ In the absence of the statute, however, it would have been difficult to recognize the injury as sufficient to open the courthouse doors. Indeed, Justice White in concurrence commented that he "would have great difficulty in concluding" that standing was satisfied but for the statute. ${ }^{24}$ Similarly, in Havens Realty Corp. v. Coleman, ${ }^{25}$ the Court recognized that housing testers-who had no interest in renting or purchasing homes-had standing to challenge the owner's refusal to sell or lease principally because Congress had conferred on "all 'persons' a legal right to truthful information about available housing." During this period, Congress created a wide variety of citizen suits, particularly in environmental contexts. ${ }^{27}$

17. See Sunstein, supra note 15 , at 188 .

18. See United States v. Students Challenging Regulatory Agency Procedures, 412 U.S. 669, 683-90 (1973); Association of Data Processing Serv. Orgs., Inc. v. Camp, 397 U.S. 150, 15254 (1970).

19. See, e.g., Schlesinger v. Reservists Comm. to Stop the War, 418 U.S. 208 (1974); Sierra Club v. Morton, 405 U.S. 727 (1972); Laird v. Tatum, 408 U.S. 1 (1972).

20. 409 U.S. 205 (1972).

21. See id. at 206-207.

22. See id. at 210.

23. See id. at 212.

24. See id. (White, J., concurring).

25. 455 U.S. 363 (1982).

26. See id. at 377. See also Bennett v. Spear, 520 U.S. 154, 163-168 (1997) (addressing Congress's role in creating citizen suits).

27. The Court's decision in Morton, 405 U.S. 727, provided a blueprint when it denied standing in an environmental context only because there was no individual injury or stake asserted. See, e.g., Toxic Substances Control Act, 15 U.S.C. § 2619 (1994); Clean Water Act of 1976, 33 U.S.C. § 1365 (1994); Safe Drinking Water Act, 42 U.S.C. § 300j-8 (1994 \& Supp. IV 1998); Solid Waste Disposal Act, 42 U.S.C. $\$ 6972$ (1994); Air Pollution Prevention and Control 
The Court's recognition that Congress can create interests whose violation gives rise to Article III injury should not be surprising. Since the inception of the country, Congress has accomplished the same result by creating property interests. Pursuant to Congress's power to "grant Letters of Marque and Reprisal," 28 for example, early Congresses authorized the President to commission private ships to capture enemy vessels trading with the enemy. Those armed with the letters of marque could tow the captured vessel into the United States' jurisdiction and then file an in rem action in federal court seeking a declaration of ownership. ${ }^{29}$ But for the congressional action, private parties could not have asserted any property ownership in the vessels seized, and could not have established standing. More recently, congressional creation of property-type interests (though not full entitlements) in the electromagnetic spectrum ${ }^{30}$ and sulfur dioxide $^{31}$ similarly allows permit parties to assert standing that they otherwise would have lacked to contest government action.

Congress plays a critical role in determining which parties should be permitted to sue for what type of injuries. Congress helps determine the parameters of a case or controversy under Article III of the Constitution. Members of Congress, like members of the Court, have an independent obligation to interpret and defend the Constitution.

In Lujan, however, the Court for the first time $\mathrm{e}^{32}$ blunted a congressional effort to create a new interest whose violation could give rise to injury in fact. Under the Endangered Species Act (ESA), Congress directed agencies to consult with the Secretary of the Interior to ensure that actions funded by them were "not likely to jeop-

(Clean Air) Act, 42 U.S.C. § 7604 (1994); Comprehensive Environmental Response, Compensation and Liability Act (CERCLA), 42 U.S.C. $\$ 9659$ (1994); Emergency Planning and Community Right-to-Know Act (EPCRA), 42 U.S.C. § 11046(a)(1) (1994).

28. See U.S. CONST. art. I, \& 8, cl. 11.

29. See C.J. Hendry Co. v. Moore, 318 U.S. 133, 152-53 (1943).

30. 47 U.S.C. $\S 309(j)$ (1994 \& Supp. IV 1998) (authorizing auctions of electromagnetic spectrum).

31. 42 U.S.C. $\$ 7651, \$ 76510$ (1994).

32. The Court's summary affirmation in McClure v. Reagan, 454 U.S. 1025 (1981), aff' $g 13$ F. Supp. 265 (D. Idaho 1981), arguably constitutes an earlier example. There, the Court upheld dismissal of a lawsuit challenging then Representative Abner Mikva's appointment to the bench. See 513 F. Supp at 266-67. The problem was that Mikva as a representative had voted for a pay increase for all judges in arguable violation of the Emoluments Clause. See id. at 265. Despite the fact that Congress authorized any of its members to challenge the appointment, the Court refused to reach the merits of the claim. See id. at 271. Congressional standing poses particular problems because of Congress' self-dealing in affording its members the power to help enforce the laws.

33. 16 U.S.C. $\$ 1531$ (1994). 
ardize the continued existence of any endangered species or threatened species...."34 After the Department of the Interior promulgated a regulation limiting the scope of the consultation provision to actions taken within this country, plaintiff environmental organizations sued under the citizen-suit provision codified in the ESA, ${ }^{35}$ asserting that the lack of consultation increased the chance that federal agency funds would support projects abroad that would threaten endangered species. ${ }^{36}$ For example, they focused on federal support for rehabilitating the Aswan High Dam, which threatened the habitat of the endangered Nile crocodile. ${ }^{37}$

The Court found the individual injury too indirect, and thus focused on whether the congressional authorization for suit supplied the requisite interest to create the injury in fact that was otherwise missing. The Court concluded that congressional authorization would not satisfy the standing requirement. The Court independently scrutinized the congressional grant of standing to ensure that the injury was sufficiently individuated:

To permit Congress to convert the undifferentiated public interest in executive officers' compliance with the law into an "individual right" vindicable in the courts is to permit Congress to transfer from the President to the courts the Chief Executive's most important constitutional duty, to "take Care that the Laws be faithfully executed." 33

At least in suits against the federal government, Justice Scalia warned that private lawsuits-in the absence of particularized injuries-impeded the Executive's ability to execute the law faithfully. Otherwise, private citizens, and not the Executive, would be enforcing public law. Through private suits, individuals would decide, at least in part, how to implement congressional regulatory objectives. Article II concerns thus shaped the Court's analysis of Article III. ${ }^{39}$

34. 16 U.S.C. $\S 1536(a)(2)$.

35. 16 U.S.C. $\$ 1540(\mathrm{~g})$.

36. See Lujan v. Defenders of Wildlife, 504 U.S. 555, 562-563 (1992).

37. See id. at 563 .

38. Id. at 577; see also Printz v. United States, 521 U.S. 898, $921-922$ (1997) (elaborating further Justice Scalia's views pertaining to congressional direction that state officers-as opposed to private parties-execute the laws in investigating applicants for gun ownership: "[T]he insistence of the Framers upon unity in the Federal Executive-to ensure both vigor and accountability-is well known. That unity would be shattered, and the power of the President would be subject to reduction, if Congress could act as effectively without the President as with him, by simply requiring state officers to execute its laws")(citations omitted).

39. The problem may be one not of interfering with the President's duty to take care to enforce the laws faithfully, but rather with the President's status as the sole official charged with 
The Lujan opinion acknowledged that cases or controversies may be created by statutes creating legal rights, but stated "that in suits against the Government, at least, the concrete injury requirement must remain.. ${ }^{40}$ Justice Kennedy in concurrence presented a more accommodating position, explaining that Congress "has the power to define injuries and articulate chains of causation that will give rise to a case or controversy where none existed before." ${ }^{\text {41 }}$ But, he, too, found that the interests under the ESA were too diffuse. ${ }^{42} \mathrm{~A}$ majority of the Court, therefore, may support some deference to Congress in defining new injuries, but will mandate that the injuries be individuated.

The Court has invalidated congressional grants of standing outside the citizen suit context. For instance, in Raines $v$. Byrd, ${ }^{43}$ the Court considered Congress's determination in the Line Item Veto Act to permit any member of Congress to sue to challenge the constitutionality of the Act. ${ }^{44}$ Congress may have permitted members of Congress to sue because their interests as legislators would be uniquely affected by the exercise of the line item veto. The Court concluded, however, that the injury to the plaintiff members of Congress was too indirect and explained that "[i]t is settled that Congress cannot erase Article III's standing requirements by statutorily granting the right to sue to a plaintiff who would not otherwise have standing." ${ }^{45}$ No mention of deference was made.

In Lujan and Byrd the Court focused exclusively on injury in fact. For the past thirty years, however, the Court has also stressed that causation and redressability constitute independent requirements a litigant must meet to satisfy standing under Article III. ${ }^{46}$ With re-

the responsibility to represent the interest of the nation as a whole. See Krent \& Shenkman, supra note 14 , at $1801-1808$.

40. See 504 U.S. at 578.

41. See id. at 580 (Kennedy, J., concurring).

42. See id. at $579-580$ (Kennedy, J., concurring).

43. 521 U.S. 811 (1997).

44. 2 U.S.C. $\$ 692(a)(1)$ (Supp. V 1999).

45. See 521 U.S. at 820 n.3. The Court in Federal Election Commission v. Akins relaxed some of Lujan's rigor. See 524 U.S. 11 (1998). There, the Court held that a party enjoyed standing to challenge the agency's failure to subject a particular lobbying group, AIPAC, to reporting and registration requirements. See id. at 11-12. Even though the informational injury was shared with many others not participating in the lawsuit, the Court reasoned that the concrete nature of the injury-the lack of information-made injury in fact easier to determine. See id. at 24. The Akins decision appears to conform to the requirements set forth in Justice Kennedy's concurrence in Lujan.

46. See, e.g., Allen v. Wright, 468 U.S. 737, 751 (1984). 
spect to the redressability hurdle, all plaintiffs must demonstrate that the relief sought can provide them with some tangible benefit. For instance, in Linda R.S. v. Richard $D .^{47}$ an unwed mother sued to force prosecution of the child's father for failure to pay child support. The Court acknowledged the injury, but concluded that plaintiff lacked standing because a favorable decision would not necessarily "result in payment of support." 48 The Linda R.S. decision contemplated that courts don a forecasting cap to gauge whether any relief might have a measurable impact on plaintiff. Redressability constituted an additional obstacle to surmount for any plaintiff vindicating an interest in federal court. Similar analysis led to findings of a lack of redressability in Warth v. Seldin ${ }^{49}$ and in Simon v. Eastern Kentucky Welfare Rights Organization. ${ }^{50}$

If the injury would not be redressed, then a judicial resolution would resemble an advisory opinion, and would suffer from the same vices. Courts would be addressing important questions that they otherwise could avoid, and might thereby become embroiled in political disputes. Judicial resources might be squandered, and the respect due the judiciary as an independent branch of government might be jeopardized. Moreover, redressability ensures that issues are presented to the courts "with that clear concreteness provided when a question emerges precisely framed and necessary for decision...."51 Finally, the absence of any concrete consequences might lift modest constraints upon judges because they are more often free to change the law if the stakes are lower. ${ }^{52}$ In other words, it is easier for courts to issue decisions with little direct consequences-such as a directive in Lujan to the Department of the Interior to consult more broadlythan when the results are more palpable.

In addition, the redressability inquiry helps weed out ideological plaintiffs. Courts may prevent such plaintiffs, to the extent possible,

47. 410 U.S. 614 (1973).

48. See id. at 618.

49. 422 U.S. 490 (1975) (finding insufficient evidence that low cost housing would have been available but for allegedly discriminatory practices of defendants).

50. 426 U.S. 26 (1976) (finding insufficient likelihood that defendants would have provided more hospital care to indigents even in absence of alleged unlawful regulation).

51. See Flast v. Cohen, 392 U.S. 83, 96 (1968). See also Federal Election Commission v. Akins, 524 U.S. 11, 24-25 (1998); Evan Lee, Deconstitutionalizing Justiciability: The Example of Mootness, 105 HARV. L. REV. 605, 644-45 (1992).

52. Cf. Harper v. Virginia Dep't of Taxation, 509 U.S. 86, 105 (1993) (Scalia, J., concurring) (deciding cases without impact on the parties is "the handmaid of judicial activism"); Desist v. United States, 394 U.S. 244, 256-69 (1969) (Harlan, J., dissenting). 
from using courts as a platform from which to pursue political agendas. ${ }^{53}$ Judges should only use resources to resolve disputes when they have the capacity to provide some tangible relief to an injured plaintiff.

Indeed, although the majority in Lujan found that the injury asserted was not imminent enough to satisfy the injury in fact requirement, a plurality stressed that " $[\mathrm{t}]$ he most obvious problem in the present case is redressability." be bound by any judgment, and even if the federal funding agencies withdrew support for the projects, "it is entirely conjectural whether the non-agency activity ... will be altered." $"$ In other words, the Aswan Dam might well have been rehabilitated irrespective of the U.S. support, and the habitat for the Nile crocodile threatened. The link between any relief awarded and redress for the particular injury-defined as preservation of the Nile crocodile-was too attenuated.

The opinion did not specify whether congressional legislation could affect the Court's assessment of redressability. Indeed, the concurring opinions would have omitted all discussion of redressability in the case. ${ }^{56}$ Left undecided, therefore, was whether Congress should have any role in influencing the redressability inquiry. ${ }^{57}$

The redressability question came to the fore in Gwaltney of Smithfield, Ltd. v. Chesapeake Bay Foundation, Inc. ${ }^{58}$ There, the Court considered whether the Clean Water Act permitted citizens to sue for violations which had ceased by the time suit was filed. ${ }^{59}$ Under the citizen-suit scheme, affected individuals-in the absence of state or federal enforcement-may commence actions against any person "alleged to be in violation of" federal requirements ${ }^{60}$ after affording

53. As Professor Stearns notes in this symposium, ideological plaintiffs may try to manipulate the Supreme Court's agenda to ensure a favorable precedent. See generally Maxwell L. Stearns, From Lujan to Laidlaw: A Preliminary Model of Environmental Standing, 11 DUKE ENVTL. L. \& POL'Y F. 321 (2001).

54. See Lujan v. Defenders of Wildlife, 504 U.S. 555, 568 (1992).

55. See id. at 571.

56. See id. at 580 (Kennedy, J., concurring).

57. The Court determined that there was redressability in Bennett v. Spear, without inquiring into Congress' role in illuminating the link between asserted injury and relief sought. See 520 U.S. 154, 155 (1997). There, plaintiff sued under the Endangered Species Act for review of a Biological Opinion issued by the Fish \& Wildlife Service. See id. at 154. According to the Court, a favorable opinion would have enhanced the possibility that the federal government would have continued support for the Klamath Irrigation Project. See id. at 168-171.

58. 484 U.S. 49 (1987).

59. See id. at 56 .

60. 33 U.S.C. $\S 1365(a)(1)$ (1994). 
sixty days notice. ${ }^{61}$ A citizen may sue either for injunctive relief or to require payment of civil penalties to the federal government. ${ }^{62}$

Between 1981 and 1984, Gwaltney violated various regulatory requirements, discharging an excessive amount of pollutants. After affording the statutorily required notice, two nonprofit corporations filed suit in June 1984 alleging that their members had been harmed by the pollution and that Gwaltney "has violated ... [and] will continue to violate" the Clean Water Act. ${ }^{63}$ Gwaltney moved to dismiss the case on the ground that all violations had ended several weeks prior to suit, and that therefore it could not be said "to be in violation" of federal requirements.

The Court agreed. Largely as a matter of statutory construction, the Court determined that the "to be in violation" language in the statute required citizen-plaintiffs to "allege a state of either continuous or intermittent violation-that is, a reasonable likelihood that a past polluter will continue to pollute in the future." ${ }^{164}$ The Court continued, however, that the language could be satisfied by a "good faith allegation of continuous or intermittent violation." ${ }^{.65}$ The Court clarified that, even if the allegations later proved unfounded, jurisdiction would attach, and plaintiffs could continue seeking civil penalties payable to the government for the wholly past violations. ${ }^{66}$

In response, Gwaltney argued that allowing suit to proceed for wholly past violations would violate Article III because plaintiffs' injury would not be remediable by the suit. ${ }^{67}$ Plaintiffs could proceed only if the relief attainable-either the injunction or penalties-redressed their injury. If there were no injury at the time the suit was filed, then there was nothing left to remedy. The Court was unmoved. As long as some chance of recurrence of injury existed, the Court reasoned that the Article III case or controversy requirement was honored. ${ }^{68}$ Article III permits suits to collect civil penalties payable to the U.S. Treasury, presumably because such suits would

61. See id. at $\S 1365(\mathrm{~b})(1)(\mathrm{A})$.

62. See Gwaltney, 484 U.S. at 53.

63. See id. at 54.

64. See id. at 57.

65. See id. at 64.

66. See id. at 64-67.

67. Defendants in Gwaltney also argued, as would defendants in Laidlaw, that the suit became moot given that the offending conduct has stopped and was unlikely to recur. See Gwaltney, 484 U.S. at 50. Both Courts rejected the arguments. See id.; see also Friends of the Earth, Inc. v. Laidlaw Envtl. Servs., Inc., 528 U.S. 167, 188-194 (2000).

68. See Gwaltney, 484 U.S. at 66. 
minimize the likelihood that such future injury would occur. The majority did not elaborate on how likely the deterrent impact must be. Nor did it elaborate whether congressional direction could influence its determination of redressability. Nonetheless, as long as the chance of injury continued, then redressability and hence Article III requirements, could be satisfied.

In concurrence, Justices Scalia, Stevens, and O'Connor disagreed with the majority's approach. In their view, if no violation existed on the date the suit was filed, then "the plaintiffs would have been suffering no remediable injury in fact that could support suit." vorable result - the civil penalties-would not remedy the prior harm because the penalties were paid to the U.S. Treasury, and there was no showing that the injury was likely to recur.

The Court's decision over ten years later in Steel Company $v$. Citizens for a Better Environment ${ }^{70}$ seemingly adopted the concurrence's view in Gwaltney. There, a citizen group sued for violations of the Emergency Planning and Community Right-to-Know Act of 1986 (EPCRA). ${ }^{71}$ The company had failed to file required inventory forms in a timely manner. The EPCRA permitted a private suit to require "an owner or operator of a facility for failure ... to complete or submit an inventory form...",72 as long as no agency action was pending. ${ }^{73}$ After the plaintiff organization had notified the agency of the company's tardiness-as mandated under the EPCRA ${ }^{74}$ - the company filed the requisite forms before suit was commenced. ${ }^{75}$

In an opinion authored by Justice Scalia, the Court held that no case or controversy was established due to the lack of redressability. ${ }^{76}$ No relief could plausibly remedy the injury of late reporting. In particular, plaintiff had relied upon the availability of civil penalties, but the Court held that, because "these penalties-the only damages authorized by the EPCRA-are payable to the United States Treasury," the plaintiff "seeks not remediation of its own injury-reimbursement for the costs it incurred as a result of late filing-but vindi-

69. See id. at 70.

70. 523 U.S. 83 (1998).

71. 42 U.S.C. $\$ 11046(a)(1)$ (1994).

72. See id.

73. See id. at $\$ 11046(\mathrm{e})$.

74. As under the Clean Water Act, the EPCRA incorporated a notice requirement as a prerequisite to filing suit. See id. at $\$ 11046(d)$.

75. See Steel Co., 523 U.S. at 87-88.

76. See id. at 106. 
cation of the rule of law." As in Lujan, therefore, plaintiff would be acting not on its own behalf, but rather as a shadow executive department in violation of Article II. Here, the target of the citizen suit was a private party instead of the government agency as in Lujan. Nonetheless, private suits can undermine the enforcement levels that federal agencies deem optimal. Such suits can either force the government to enter frays that they would prefer to avoid or, if the government does not intervene, result in settlements that the government might not find to be in the public's best interests. ${ }^{78}$

In addition, the Court specifically rejected the possibility that the civil penalties would redress plaintiff's injury by "deter[ring] the risk of future harm." "or the imminence of a future violation" would there be redressability ${ }^{80}$ and only then if plaintiff could demonstrate "a likelihood that the requested relief will redress the alleged injury." O'Connor and Kennedy concurred, explicitly agreeing with the redressability part of the Court's opinion. ${ }^{82}$

Justice Stevens concurred in the result, but vehemently objected to the redressability analysis. Labeling the analysis "mechanistic," $\$ 3$ he explained that

[w] hen one private party is injured by another, the injury can be redressed in at least two ways: by awarding compensatory damages or by imposing a sanction on the wrongdoer that will minimize the risk that the harm-causing conduct will be repeated. Thus, in some cases a tort is redressed by an award of punitive damages; even when such damages are payable to the sovereign, they provide a form of redress for the individual as well. ${ }^{84}$

According to Justice Stevens, remedies that enhance deterrence of future wrongdoing satisfy the redressability prong of Article III, and

77. See id.

78. See Michael S. Greve, Friends of the Earth, Foes of Federalism, 12 DUKE ENVTL. L. \& POL'Y F. 167 (2001).

79. See Steel Co., 523 U.S. at 106-07.

80. See id. at 108. Furthermore, the prospect of recovering investigation and prosecution costs was insufficient because the litigation must give the plaintiff some other benefit besides reimbursement of costs that are a byproduct of the litigation itself. See id. at 107 ("[An] interest in attorney's fees is ... insufficient to create an Article III case or controversy' where none exists on the merits of the underlying claim.") (citations omitted).

81. See id. at 110. Much of the Court's opinion can be considered dicta, however, because plaintiff evidently did not satisfy statutory standing because there was no showing that defendant was "in violation" of the Act at the time the suit was filed.

82. See id.

83. See id. at 124.

84. Id. at 127. 
thus he would have permitted plaintiff to seek civil penalties, even though payable to the United States Treasury.

The picture of redressability in Steel Company therefore apparently contrasts sharply with that in Gwaltney. In Gwaltney redressability could be demonstrated as long as any possibility of future injury existed coupled with prior injury, while in Steel Company a different coalition of judges supported the proposition that the likelihood of future injury must be greater, and the injury imminent.

The Court in Laidlaw seemingly flip-flopped again, returning to Gwaltney's analysis. As in Gwaltney, plaintiff environmental organization filed a citizen suit against a company for violations of pollution limits prescribed in the Clean Water Act. Plaintiff sought injunctive relief and penalties payable to the United States Treasury after defendant had failed to halt the discharges within the sixty-day notice period. ${ }^{85}$ Unlike in Gwaltney and Steel Company, Laidlaw was in violation of the pertinent regulations at the time plaintiff's suit was filed. By the time the case reached the Supreme Court, Laidlaw had closed the offending facility, making the likelihood of future injury extremely low. An injunction would not have been appropriate, and collection of civil penalties would not have redressed plaintiff's past injuries any more than it would have in Steel Company.

Nonetheless, the Court held that the Friends of the Earth had standing to seek the monetary penalties. Although the Court reiterated that a plaintiff must demonstrate standing separately for each form of relief sought, ${ }^{86}$ it held that private parties could seek penalties payable to the government in light of the fact that "all civil penalties have some deterrent effect." be a point at which the deterrent effect of a claim for civil penalties becomes so insubstantial or so remote that it cannot support citizen standing." 88 The Court concluded, however, that the district court had reasonably determined that the penalties were needed to effectuate deterrence on the facts of this case: "that the penalties would redress FOE's injuries by ... preventing future ones."

The majority attempted to distinguish Steel Company on the ground that the violations had ceased by the time the suit was filed.

85. See Friends of the Earth, Inc. v. Laidlaw Envtl. Servs., Inc., 528 U.S. 167, 176-177 (2000).

86. See id. at 185.

87. See id. (citing Hudson v. United States, 522 U.S. 93, 102 (1997)).

88. See id. at 186.

89. See id. at 187. 
As Justice Scalia noted in dissent, that distinction is meaningless. Imposition of civil penalties should deter future violations irrespective of whether the violations ceased one month before suit was filed or one month after. A defendant in both contexts would think twice about future violations "once hit in its pocketbook." The likelihood of future violations may differ in the two contexts, but the deterrent function of civil penalties payable to the government is identical. ${ }^{11}$

Irrespective of the date on which the violations ceased, the critical question for redressability under the Court's doctrine should be whether the prospect of future injury was sufficiently high on the day suit was filed to warrant imposition of the civil penalties. Civil penalties payable to the government redress not the prior injury, ${ }^{92}$ but are designed to minimize the likelihood of future recurrence. Perhaps, plaintiff's failing in Steel Company was that it neglected to allege that the prospect of future harm-that defendant would again fail to report its discharges-was substantial.

A comparison with the Court's decision in City of Los Angeles $v$. Lyons $^{93}$ is illustrative. There, plaintiff challenged the city's practice of encouraging law enforcement officers to subdue suspects by dint of a chokehold. The theory was that, by using chokeholds, police would not have to rely on weapons. Use of the chokeholds, however, resulted in several deaths and numerous serious injuries.

Plaintiff had been subjected to a chokehold, and sued to stop the city from engaging in the practice. The Court dismissed the suit, holding that he lacked standing to seek an injunction against continued use of the chokehold. Plaintiff could seek damages for injuries he had suffered, but in the absence of any reason to think that he would again be subjected to a chokehold, no case or controversy existed. ${ }^{94}$

If the analysis in Lyons reflects current doctrine, the question in environmental citizen suits should be whether plaintiffs have demon-

90. See id. at 186.

91. Thus, the Court has come full circle since Gwaltney. The Court initially determined that civil penalties payable to the federal government, by deterring future misconduct, satisfied redressability. See Gwaltney, 484 U.S. 49, 66 (1987). Then, the Court in Steel Company held that redressability could not be justified unless the likelihood of future injury was high and the threat imminent. See 523 U.S. 83, 106 (1998). Finally in Laidlaw, the Court once again determined that penalties can redress injuries by deterring future misconduct, even when there has been no concrete demonstration of a likelihood of recurring harm. See 528 U.S. at 186. large.

92. As long as the injury conceptualized is that of the plaintiff, as opposed to the public at

93. 461 U.S. 95 (1983).

94. See id. at 105-09. 
strated a sufficient risk of future harm to justify the civil penalty award. The record in neither Steel Company nor in Laidlaw convincingly demonstrated such risk.

The Court in Laidlaw, however, seemingly deferred to Congress's decision to create particular remedies in the Clean Water Act. It stated:

Congress has found that civil penalties in Clean Water Act cases do more than promote immediate compliance by limiting the defendant's economic incentive to delay its attainment of permit limits; they also deter future violations. This congressional determination warrants judicial attention and respect. ${ }^{95}$

Justice Ginsburg further stressed that " $[\mathrm{t}]$ he legislative history of the [Clean Water] Act reveals that Congress wanted the district court to consider the need for retribution and deterrence, in addition to restitution, when it imposed civil penalties. . . [The district court may] seek to deter future violations by basing the penalty on its economic impact." ${ }^{, 96}$

The structure of the statute reinforces this understanding. No damages are available for past violations. The two key remedies instead are injunctions or civil penalties payable to the United States, both designed to deter future violations. And, neither is available until after defendant is granted a sixty-day time period within which to change its conduct. Thus, once a plaintiff can demonstrate that a defendant is in violation of the Act on the date the complaint is filed, Congress presumptively intended that the other two remedies be available.

To be sure, Congress did not explicitly make any findings about redressability under the Clean Water Act. And, the statutory structure under the EPCRA similarly permits an inference that Congress determined that civil penalties would help redress continuing violations there.

The link between civil penalties and injury under the EPCRA, however, is not as intuitively compelling for three reasons. First, the Court may well have discounted Congress's role under the EPCRA in

95. Laidlaw, 528 U.S. at 185.

96. Id. (quoting Tull v. United States, 481 U.S. 412, $422-23$ (1987)). Furthermore, one of the Senate reports accompanying amendments to the Clean Water Act asserted that citizen suits "have deterred violators and achieved significant compliance gains." See S. REP. NO. 90-50, at 28 (1985). Similarly, a Senate Report supporting revisions to the Clean Air Act explained, "the assessment of civil penalties for violations of the [Clean Air] Act [is] necessary for deterrence, restitution and retribution." See S. REP. No. 101-228, 373 (1989). See also 136 CONG. REC. 5627 (1990) (remarks of Senator Chafee). 
determining that civil penalties were necessary to deter companies from future violations. Congress apparently adopted the Clean Air Act and Clean Water Act remedial scheme wholesale in establishing the EPCRA (as well as other environmental enforcement schemes). Congress may not have demonstrated sufficient independent concern for the efficacy of the remedial scheme in the EPCRA context. Accordingly, the Court had less reason to defer in Steel Company.

Second, the framework of the EPCRA suits supports the inference that Congress did not make any findings as to the need for civil penalties in that context. In contrast to most Clean Water Act cases, there is not likely to be a track record of numerous past violations. The situation in Laidlaw is not unique. The district court determined that Laidlaw had violated the mercury limits on 489 occasions between 1987 and 1995..$^{97}$ Environmental groups monitoring discharges seldom sue after one random violation, but only after a pattern has been discerned. After 489 separate violations spanning an eight-year period, the presumption that such discharges will continue absent a deterrent is strong. In comparison, there was only a single violation alleged in Steel Company. There was less reason, therefore, to assume that the defendant would continue to violate the Act in the future. ${ }^{98}$

Third, and related, defendants who violate the Clean Water Act arguably are more culpable than their counterparts under the EPCRA. Officials in such companies are well aware of the legal requirements, and well aware of the magnitude of their discharges. They can monitor effluent levels just as readily as can the Friends of the Earth and other environmental organizations. From the prior conduct, one can presume a continued risk of lawlessness, as indeed occurred in Laidlaw. Companies that have knowingly discharged excessive contaminants are likely to continue illegal discharges in the future. On the other hand, under the EPCRA, companies may violate the Act inadvertently, either by failing to file in a timely fashion, or by presenting information that the agency deems misleading. Viola-

97. See Laidlaw, 528 U.S. at 176.

98. The fact patterns of the two cases also differ in that the defendant in Steel Company cured the defect within the sixty-day period, unlike the defendant in Laidlaw. See Laidlaw, 528 U.S. at 176; Steel Co., 523 U.S. 83, 87-88. When a defendant takes vigorous steps to stop the offending conduct quickly, the presumption of recurring violations has less force. In sharp contrast, the defendant in Laidlaw violated the mercury discharge limit thirteen times after suit was filed, and committed an additional thirteen monitoring and ten reporting violations. See 528 U.S. at 176. The Court's finding of no standing in Steel Company reflected its conviction that the likelihood of continuing injury after defendant's voluntary compliance was low. 
tions may stem from negligence as opposed to knowing behavior. The difference in level of culpability may be critical, for a prior violation under the EPCRA may not be indicative of future violations. Thus, in light of the different probabilities of recurring harm, the Court was more willing to defer to congressional creation of civil penalties under the Clean Water Act: a presumption of continuing harm only exists in that context.

In short, Congress under both the Clean Water Act and the EPCRA determined that civil penalties payable to the government should be available to private plaintiffs. But only under the Clean Water Act did Congress make its reasoning clear, and that context more fully supports the premise that defendants who have violated statutory requirements are quite likely to violate them again in the future.

Congress could have made the link between past and future injuries under the Clean Water Act more explicit, and any such findings may well have aided the Court in reaching its redressability analysis. Familiarity with the dynamics of Clean Water Act suits evidently persuaded the Court to defer to the congressional scheme, despite Congress's lack of detailed findings. Laidlaw therefore illustrates Congress's critical role in determining that particular remedies are likely to redress particular harms.

Accordingly, this Part briefly sketches the normative assumption underlying Laidlaw - courts should defer to congressional determinations that selected remedies will likely deter particular harms. Such congressional determinations may be implicitly reflected in the logic or legislative history of the enforcement scheme, in explicit legislative findings, or in creation of statutory mechanisms such as nominal damages or bounties designed to ensure that an individual's interest in an action be redressable by a favorable judgment. In any of the contexts, Congress's determination that citizens should be able to sue for particular remedies warrants deference.

Deferring to legislative findings explicitly or implicitly supporting the redressability of a particular injury comports with traditional separation of powers principles for a number of reasons. First, careful empirical work by legislatures can persuade judges of causal connections that may have seemed a stretch at first glance. The redressability inquiry turns on the likelihood that a particular remedy will redress the plaintiff's injury. Because of its wide-ranging nature, con- 
gressional fact finding might assess the possibility of remediation better than efforts by judges or their clerks.

Even in Lujan, the concurring and dissenting Justices recognized the special role for Congress in creating interests whose violation can give rise to a cognizable injury in fact. In comparison to implicit congressional declarations as to injuries in fact in Lujan or Raines, there is greater reason to defer to fact finding or determinations as to the connection between particular remedies and the injuries alleged.

As an initial matter, factual analysis bears on whether the link between remedy and potential for future violations exists. Courts may not have the empirical data to assess whether particular companies are likely to continue violations after a complaint is filed. Judgments "on the deterrent effect of the various weapons in the armory of the law can lay little claim to scientific basis. Such judgment as yet is largely a prophecy based on meager and uninterpreted experience." ${ }^{99}$ Moreover, courts may not have experience in gauging whether the prospect of civil penalties deters effectively. Some remedies such as injunctions are likely more effective than awards of nominal damages and perhaps civil penalties as well. In addition, the deterrent effects of remedies may differ depending upon the statutory context, the size of the defendant, and the ease of compliance. Such congressional determinations can therefore aid the Court in assessing whether a particular remedy is likely to redress a potential harm, such as the harm in Laidlaw of recurring discharge of pollutants in excess of permissible levels.

Moreover, courts may wish to monitor the injury in fact determination more than redressability because of their gatekeeper role. Courts will face fewer conflicts with the coordinate branches if particular interests-whether interests in effective enforcement of the law or in environmental health-fall outside those recognized as satisfying the injury in fact test. Once injury in fact is satisfied, the number of cases avoided by enforcing redressability strictly is not as great. Thus, courts arguably should be willing to defer to congressional determinations more in the redressability context.

Indeed, factual issues often inform constitutional analysis. For instance, the Supreme Court in United States v. Lopez ${ }^{100}$ adverted to the advantages of legislative findings in demonstrating a link between

99. Tigner v. Texas, 310 U.S. 141, 148 (1940).

100. 514 U.S. 549 (1995). 
regulation and the flow of interstate commerce. ${ }^{101}$ The majority commented that, "to the extent that congressional findings would enable us to evaluate the legislative judgment that the activity in question substantially affected interstate commerce, even though no such substantial effect was visible to the naked eye, they are lacking here."102 The concurring opinion suggested the result might have been different had congressional findings illuminated the commercial character of the regulation prohibiting possession of a firearm near schools. ${ }^{103}$ In dormant commerce clause cases as well, the Court has asked whether legislative findings demonstrate that a challenged state regulation will bring legitimate safety and health effects. ${ }^{104}$ Commercial speech regulation may turn on the need to protect consumers from confusion or misrepresentation. ${ }^{105}$ As the Supreme Court recently reiterated in Turner Broadcasting System, Inc. v. FCC, ${ }^{106}$ "courts must accord substantial deference to predictive judgments of Congress." 107

101. See id. at 562 .

102. Id. at 563 .

103. See id. at 580 (Kennedy, J., concurring). When Congress builds a record, as it has, for instance, under the Freedom of Access to Clinic Entrances Act of 1994, 18 U.S.C. § 248 (1994), the federal carjacking statute, 18 U.S.C. $\$ 2119$ (1994 \& Supp. IV 1998), the Child Support Recovery Act of 1992, 18 U.S.C. $\S 228$ (1994 \& Supp. IV 1998), and the Child Restoration and Penalties Act of 1990, 18 U.S.C. $§ 2252$ (1994 \& Supp. IV 1998), the task of reviewing courts is lightened. Instead of speculating as to the connections between the regulation and interstate commerce-as Justice Breyer did in the Lopez dissent-courts rather can rely on the empirical bases demonstrated in the congressional findings. Most would agree that Congress has better factfinding capabilities than do courts. Thus, directing Congress to build a record can streamline-and sharpen-the judicial task of reviewing federal legislation for conformity to the Commerce Clause.

104. See, e.g., C \& A Carbone, Inc. v. Clarkstown, 511 U.S. 383 (1994) (inquiring into health and environmental safety reasons for a waste control ordinance favoring a local business); Kassel v. Consolidated Freightways Corp., 450 U.S. 662, 705-09 (1981) (inquiring into safety reasons for state rule burdening national trucking companies).

105. See Posados de Puerto Rico Assocs. v. Tourism Co., 478 U.S. 328, 333-34 (1986) (upholding regulation of advertising of casino gambling aimed at Puerto Rico citizens in part because "[w]e have no difficulty in concluding that the Puerto Rico Legislature's interest in the health, safety, and welfare of its citizens constitutes a 'substantial' governmental interest"). See also Nixon v. Shrink Mo. Gov't PAC, 528 U.S. 377, 390-393 (2000) (deferring to legislative judgments about level of corruption engendered by certain campaign practices); Colorado Republican Fed. Campaign Comm. v. Federal Election Comm'n, 518 U.S. 604 (1996) (discussing usefulness of congressional finding in demonstrating the corruption that supports campaign finance regulation). And, in Eleventh Amendment cases, congressional findings may shed light on whether Congress can authorize individuals to sue states for violations of federal law. See Kimel v. Florida Bd. of Regents, 528 U.S. 62 (2000); Union Pac. R.R. v. Utah, 198 F.3d 1201 (10th Cir. 1999).

106. 520 U.S. 180 (1997).

107. Id. at 196. 
One might wonder whether courts should defer at all to legislative findings in constitutional cases. In Bose Corp. v. Consumers Un$i{ }^{103}$ the Court held that factual determinations in certain areas of the law such as under the actual malice standard in libel law must be independently reviewable on appeal. ${ }^{109}$ To ensure superintendence over the constitutional claim, appellate courts can review factual findings more stringently. Courts might afford even less deference to fact finding by political actors. Under the now discredited constitutional fact doctrine in administrative law, for instance, courts retained the discretion to retry all factual determinations made by agencies to preserve full control over the constitutional claims. ${ }^{110}$ Otherwise, factual findings could unduly influence the availability of relief under the Constitution.

But deference to the findings of a coordinate branch of government cannot be equated with capitulation. The Court explained in Turner Broadcasting that "[w]e owe Congress' findings deference in part because the institution is far better equipped than the judiciary to amass and evaluate the vast amounts of data bearing upon legislative questions." 111

Indeed, the Court this past term in United States v. Morrison ${ }^{112}$ stressed that "the existence of congressional findings is not sufficient, by itself, to sustain the constitutionality of Commerce Clause legislation."113 The Court criticized Congress for relying in its findings on "reasoning" previously rejected by the Court. ${ }^{14}$ Although courts should not defer to Congress's assessment of the legality of its own legislation, they have deferred to the superior fact finding ability of a coordinate branch of government including Congress's "findings as ... to the remedial measures adopted....,115

108. 466 U.S. 485 (1984).

109. See id. at $501 \mathrm{n} .17$.

110. See Ng Fung Ho v. White, 259 U.S. 276 (1922); Ohio Valley Water Co. v. Ben Avon, 253 U.S. 287 (1920).

111. 520 U.S. at 195.

112. 529 U.S. 598 (2000).

113. See id. at 673-74.

114. See id. As the dissent pointed out, the findings in Morrison were far more probative and careful than in many prior cases. See id. at 682-86 (Thomas, J., dissenting). The Court in the last several terms has accorded less deference to the judgment of the coordinate branch. See, e.g., Dickerson v. United States, 530 U.S. 428 (2000); City of Boerne v. Flores, 521 U.S. 507 (1997).

115. See Turner Broadcasting Sys., Inc. v. FCC, 520 U.S. 180, 196 (1997). 
For a variety of reasons, the current Court will likely defer more to explicit than implicit findings. Some members of the Court have shied away from attention to congressional intent drawn from committee reports, hearings, and the like. Justice Scalia in particular has noted the unreliability of such materials. As he explained in Wisconsin Public Intervenor v. Mortier, ${ }^{116}$

[a]ll we know for sure is that the full Senate adopted the text that we have before us here, as did the full House, pursuant to the procedures prescribed by the Constitution ... we should try to give the text its fair meaning, whatever various committees might have had to say-thereby affirming the proposition that we are a Government of laws, not of committee reports. ${ }^{117}$

According meaning to legislative history may sanction lawmaking outside the constitutionally prescribed procedures of bicameralism and presentment. Danger resides on a more practical level in vesting too much power in committee reports and the like-which may well have been written by staff members and interest groups.

Nonetheless, Justice Scalia's views in this respect have not commanded a majority. The Court has relied on such evidence in considering a variety of issues, including whether Congress provided a clear statement of its intent to regulate states or to subject the federal government to suit. ${ }^{118}$ The more explicit the findings, however, the less controversial and the greater the deference that likely will be shown. Part of the rationale for deferring to Congress's assessment of redressability, therefore, turns on its comparative advantage in factfinding.

A second justification rests on concern for a due process of lawmaking. Encouraging the use of legislative findings may promote greater deliberation as to the wisdom of congressional authorization for particular individuals to sue. Congress arguably should exercise care in determining which parties are appropriate in which contexts to bring suit. To be sure, members of Congress may relegate responsibility to craft such findings to staffers. Few members of Congress

116. 501 U.S. 597 (1991).

117. Id. at 621 (Scalia, J., concurring). See also Thompson v. Thompson, 484 U.S. 174, 191-92 (1988) (Scalia, J., concurring) (stating that "[c]ommittee reports ... are frail substitutes for bicameral vote upon the text of a law and its presentment to the President"); INS v. CardozoFonseca, 480 U.S. 421, 452-53 (1987) (Scalia, J., concurring).

118. See, e.g., Kimel v. Florida Bd. Of Regents, 528 U.S. 62 (2000); Hilton v. South Carolina Pub. Ry. Comm'n, 502 U.S. 197 (1991); Welch v. Texas Dep't of Highways \& Public Transp., 483 U.S. 468 (1987); cf. Environmental Defense Fund v. Costle, 636 F.2d 1229 (D.C. Cir. 1980) (considering legislative history in search for clear statement needed to supplant prior consent decree). 
read reports or summaries of hearings; for that matter, few may read the intricate text of voluminous bills. But in some cases, the need to make findings may itself prompt greater debate as to what kind of findings to place in the statute. Indeed, in the exceptional case, legislation may not only be slowed but altered due to the difficulty members of Congress (or staffers) have in making a convincing nexus between a particular remedy and the injury suffered.

In this respect, required findings operate like clear statement rules of statutory construction, which the Court has applied-albeit not always consistently-when reviewing legislation that trenches upon Tenth ${ }^{119}$ and Eleventh Amendment concerns. ${ }^{120}$ The Court will not interpret a statute to invade a core state function or subject a state to suit in federal court in the absence of a clear statement. A clear statement approach adds costs to legislation, but at the same time attempts to prompt Congress to deliberate more forthrightly about the wisdom of such legislation. ${ }^{121}$ As the Court stated in Gregory v. Ashcroft, ${ }^{122}$ the clear statement rule ensures "that the legislature has in fact faced, and intended to bring into issue, the critical matters involved." 123

Congress arguably should not open the courthouse doors unless it has broad-based political support. It should only permit wide ranging inquiry into executive branch administration of the laws when it is on firm terrain. When the Court is skeptical about the nature of a plaintiff's injuries or motives, congressional findings reassure the Court that Congress has in fact determined that such suits are appropriate. Findings, like clear statement rules, help ensure that congressional action impinging on Article III (or Article II) concerns is a product of reflection and deliberation.

Third, encouraging a legislative record opens up the legislative process to greater public scrutiny. Individuals can better assess the basis for congressional action. When the link (or lack thereof) between fines and continued polluting is better understood, citizens can

119. See, e.g., Gregory v. Ashcroft, 501 U.S. 452 (1991).

120. See, e.g., Kimel, 528 U.S. 62; Atascadero State Hosp. v. Scanlon, 473 U.S. 234 (1985); cf. Vermont Agency of Natural Resources v. United States ex rel. Stevens, 120 S. Ct. 1858, 1866-67 (2000) (stating that the presumption that the term "person does not include the sovereign" may "be disregarded only upon some affirmative showing of statutory intent to the contrary").

121. See generally John C. Nagle, Waiving Sovereign Immunity in an Age of Clear Statement Rules, 1995 WIS. L. REV. 771; William N. Eskridge \& Philip P. Frickey, Quasi-Constitutional Law: Clear Statement Rules as Constitutional Lawmaking, 45 VAND. L. REV. 593 (1992).

122. 501 U.S. 452 (1991).

123. See id. at 461 (citations omitted). 
hold their representatives more accountable for their actions. In essence, legislative findings reduce the cost to the public of understanding and then monitoring their legislative agents' actions.

In short, the Court's deference in Laidlaw to Congress's decision to provide civil penalties under the Clean Water Act as a means to deter future wrongdoing is normatively appealing. Even though the structure of the statutory scheme in the EPCRA is similar, the different social and economic contexts may have convinced the Court that there was no reason to presume a high probability of continuing injury.

If Congress, however, would have made findings suggesting that a single failure to file an accurate report under the EPCRA likely leads to repeated violations, then the Court would have had to address the linkage between remedy and future injury more directly. Depending upon the strength of the legislative showing, the Court might have been persuaded to recognize the likelihood of recurring injury as it did in Laidlaw. Deference to congressional fact finding makes sense both as a matter of policy and formal separation of powers doctrine.

\section{III}

Courts, however, should place limits on Congress's efforts to influence the redressability inquiry. Judges should not blindly accept congressional statements or efforts to legislate away any redressability concerns for a number of reasons. First, given that redressability remains part of standing, courts should exercise the authority to determine the bounds of the case or controversy requirement rooted in Article III. Second, even when Congress has plausibly fashioned a link between a particular remedy and harm on the wholesale level, the congressional forecast of the likelihood of continuing injury, or a congressional assessment of the deterrent effect of a selected remedy, may fall apart in a given case. Third, due to separation of powers concerns, courts maintain an appropriate role in ensuring that Congress follows particular procedures in designing the congressional mechanisms that assure redressability-Congress must ensure that redressability is demonstrated apart from a stake in the litigation itself.

\section{A. Judicial Review}

Under the Supreme Court's contemporary view, standing doctrine constitutes a critical component of the case and controversy re- 
quirement of Article III. Courts understandably will review congressional efforts to confer standing on individuals to safeguard the values underlying standing doctrine. As the Court stated in Raines, "Congress cannot erase Article III's standing requirements by statutorily granting the right to sue to a plaintiff who would not otherwise have standing." ${ }^{124}$ Absent review, Congress would have plenary authority to link particular remedies to common law or statutory injuries that have scant connection.

For instance, assume that Congress authorized all persons to challenge unlawful conduct by the FBI. Congress further might declare that individuals, assuming injury in fact, will benefit from a finding of illegality by receiving assurance that the government is operating within the confines of the law. Courts presumably would find such congressional declaration insufficient to demonstrate that a favorable resolution of the suit would redress the injury. ${ }^{125}$ Alternatively, Congress may rely on such weak statistical inferences in making its connections between injury suffered and remedy selected as to forfeit any deference. The remedial scheme under the EPCRA may represent such a case. Judicial review protects the core requirements of a concrete dispute and adverse parties that delimit the bounds of Article III.

\section{B. Overcoming Congressional Findings in Specific Cases}

Moreover, any congressional determination as to the connection between relief and injury may not hold in the particular circumstances of a case. Standing doctrine contemplates that plaintiffs in particular cases enjoy a sufficient stake in the controversy to invoke the Court's authority. Standing is evaluated at the retail, not the wholesale level.

Thus, although congressional determinations or findings as to redressability as in Laidlaw merit deference, the presumption of redressability should be rebuttable. Congressional determinations as to the likelihood of recurring harm or as to the effectiveness of deterrent measures make sense only in the aggregate. Congress could not possibly foresee all of the contexts in which the question of redressability could arise. A congressional determination that a particular remedy

124. See Raines v. Byrd, 521 U.S. 811,820 n.3 (1997).

125. See, e.g., Allen v. Wright, 468 U.S. 737, 754 (1984) (noting that the "right to have the Government act in accordance with law is not sufficient, standing alone, to confer jurisdiction on a federal court"); Linda R.S. v. Richard D., 410 U.S. 614 (1973); Associate Builders \& Contractors v. Hovey Elec., 16 F.3d 688 (6th Cir. 1994) (rejecting efforts by plaintiffs to require the state to enforce the law). 
redresses a harm in the generality of cases is entitled to respect, but the individual characteristics should still be considered. ${ }^{126}$ This is not to suggest that defendants can overcome a presumption of redressability by arguing that damages or penalties will not successfully deter them in the future. When Congress determines that penalties such as cease and desist orders or injunctions are appropriate, courts should accept their deterrent effect. Nor can defendants argue that such relief is unnecessary because they will not violate the law in the future. ${ }^{127}$ But, defendants should be able to point to any extraordinary reasons arising prior to initiation of the lawsuit-such as technological or statutory changes-that make resumption of the wrongful conduct highly unlikely. If there is no realistic chance that defendants' conduct will again harm plaintiff, then plaintiff has nothing at stake in seeking deterrent remedies, whether they take the form of an injunction, damages, or penalties payable to the government.

The same, of course, is true with congressional creation of injuries. Congress can recognize an interest in environmental quality, but someone who does not live near the disputed region still cannot sue. In Trafficante, the Court respected Congress's determination that a tester could sue, but a tester who did not actually apply to the particular housing units could not challenge the housing policies. Similarly, with respect to redressability, a defendant under the Clean Water Act can try to establish, as Laidlaw tried, that it is unlikely to violate the Act in the future given unique circumstances, despite the legislation. ${ }^{128}$ District courts should have the discretion to make the

126. In this respect, the Court's analysis departs from Professor Fletcher's recommendation that redressability be considered only at the "wholesale" level. See Fletcher, supra note 15, at 242-43. If the only question were whether Congress has conferred a cause of action, then redressability would only be considered at the greater level of generality. But, given the Court's insistence that litigants in each lawsuit demonstrate a concrete injury and that it be redressable, the connection between relief sought and the injury suffered must be assessed in particular cases. In Lyons, for example, the Court may have held that even Lyons' injury was redressable if he could have marshaled empirical evidence demonstrating a greater possibility that he would be subject to another chokehold.

127. Cf. United States v. W.T. Grant Co., 345 U.S. 629, 632 (1953) (stating that a case is not mooted when "defendant is free to return to his old ways")

128. In determining standing, the Court relies on the factual context at the time the suit is filed. See Lujan v. Defenders of Wildlife, 504 U.S. 555, 571 n.4 (1992) (explaining that standing is "assessed under the facts existing when the complaint is filed"); Gwaltney of Smithfield, Ltd. v. Chesapeake Bay Found., Inc., 484 U.S. 49, 69 (1987) (Scalia, J., concurring) (stating that "[s]ubject matter jurisdiction depends on the state of things at the time of the action brought") (citation omitted); Carr v. Alta Verde Indus., Inc., 931 F.2d 1055, 1061 (5th Cir. 1991) (stating that "standing is determined as of the date of the filing of the complaint"). Thus, even if the likelihood of recurring injury becomes either greater or less as the suit progresses, courts will not take that into account in determining redressability. Indeed, in Laidlaw, the potential for 
ultimate call as to whether the relief sought will redress injury, but the determinants-and presumption of redressability-are set by Congress.

\section{Limits of Congressional Mechanisms to Assure Redressability}

In lieu of findings, Congress at times seeks to ensure redressability by altering the legislative scheme so that plaintiffs receive tangible benefits from pursuing the suit. Although courts should allow Congress wide latitude in shaping the relief attainable, such relief must redress an interest apart from the litigation itself.

Payment of monetary damages, irrespective of the form, constitutes the traditional means of redressing injury. Plaintiffs injured by torts or breaches of contract can recover damages as one means of redressing the injury. If Congress had authorized the plaintiffs in Laidlaw or Lujan to recover damages (liquidated or otherwise) to compensate them in part for the environmental and procedural injuries suffered, then the remediation principle would be honored. There might be a point at which congressional creation of a damages remedy would fail to redress a particular injury. Nonetheless, almost every congressional provision of a damages remedy should satisfy the redressability requirement.

Congress similarly might try to overcome any redressability obstacles by authorizing punitive or nominal damages awards. Such damage awards are not directly linked to the injuries suffered. Punitive damages punish the offender, and the amount of the award is not commensurate with restoring plaintiff to its rightful position. ${ }^{129}$ As the Supreme Court recently summarized, "[p]unitive damages may properly be imposed to further a State's legitimate interests in punishing unlawful conduct and deterring its repetition." that a recovery of punitive damages satisfies redressability if the plaintiff has in fact suffered injury. The recovery might be more than necessary to redress the injury, but that should not offend any Article III requirement. The redressability requirement does not impose any

recurrence was extremely low at the time the Supreme Court considered the case because the offending plant had been shut down.

129. See BMW of N. Am. v. Gore, 517 U.S. 559 (1996); Browning-Ferris Indus. v. Kelco Disposal, Inc., 492 U.S. 257 (1989) (noting that "the practice of awarding damages far in excess of actual compensation for quantifiable injuries ... date[s] back to the thirteenth century"); Silkwood v. Kerr-McGee Corp., 464 U.S. 238 (1984).

130. Gore, 517 U.S. at 568. 
obligation that the congressional remedy be closely tailored to the injury suffered, just that there be some redress. ${ }^{131}$

The Court, however, must ensure that plaintiff has suffered some cognizable injury that the punitive damages can redress. If the punitive damages award does not help remedy the harm, then the absence of redressability would convert plaintiff into a private attorney general.

For instance, consider Plotkin and the Better Government Association $v$. Ryan. ${ }^{132}$ There, a registered Illinois voter and political watchdog group alleged that the Secretary of State's office coerced employees into making contributions and performing campaign work during the gubernatorial campaign of former Secretary of State and now governor George Ryan. ${ }^{133}$ That coercion allegedly led to two separate injuries: an official subsidy for the Ryan campaign that undermined the democratic process, and more dangerous roads because employees were forced to sell drivers' licenses to cover the cost of the campaign contributions. ${ }^{134}$

With respect to the subsidy, however, defendants' actions harmed plaintiffs' interests only as voters, injuries shared with the general populace. Under Lujan, such injury cannot satisfy the Article III injury in fact test. Nor could standing be predicated on Plotkin's separate injury as a user of Illinois' roads. The relief sought, including punitive damages, would not "redress his injury." ${ }^{135}$ The punitive damages might ensure him financial comfort, but not prevent dangerous driving by those who improperly obtained licenses. And there was no likelihood that he personally would be injured by any continuing unlawful conduct, much as in Lyons. Accordingly, the court threw out the suit. ${ }^{136}$

But the punitive damages award, by providing deterrence, might redress plaintiff's injuries if a likelihood of future injury existed that could be deterred. If Plotkin had been able to show that coercion in the Secretary of State office was continuing, then the award of puni-

131. Punitive damages on occasion may be justified on the grounds that the injury may be difficult to quantify monetarily or damages might be undercompensatory, as in wrongful death cases or instances of crippling injury. See RICHARD S. POSNER, ECONOMIC ANALYSIS OF LAW 82-85 (3d ed. 1986).

132. No. 99-C 53, 1999 U.S. Dist. LEXIS 16214 (N.D. Ill. 1999).

133. See id. at $* 2-3$.

134. See id. at $* 3$.

135. See id. at $* 15$.

136. See id. at $* 20-21$. 
tive damages may have deterred that conduct. Just like civil penalties, punitive damages would make new harms much less likely. ${ }^{137}$

Nominal damages present the flipside of punitives because they provide less than full relief. An award of nominal damages, as in civil rights cases, should comparably satisfy the redressability requirement. Nominal damages can be seen as a way to redress a harm by providing moral vindication - the award stamps the defendant's actions as unjust, and provides a measure of relief for the prior injury. As the Supreme Court stated in Carey v. Piphus: ${ }^{138}$

common-law courts traditionally have vindicated deprivations of certain 'absolute' rights that are not shown to have caused actual injury through the award of a nominal sum of money. By making the deprivation of such rights actionable for nominal damages without proof of actual injury, the law recognizes the importance to organized society that those rights be [sic] scrupulously observed. ${ }^{139}$

Property rights have been protected in a similar fashion through trespass suits even when no tangible harm can be demonstrated. An award of nominal damages plainly redresses the prior injury.

An award of nominal damages, however, has a less pronounced impact on deterrence. A one-dollar fine, by itself, may not change behavior. Nonetheless, if the prospect of continuing harm exists, the damages award of even a nominal amount serves a deterrent purpose. Defendants may strive to avoid another finding of liability, and the accompanying financial or social loss. Congress, therefore, may help ensure redressability by providing for nominal damage awards as long as the award redresses prior injury or prevents recurrence of future injury.

Whether Congress can satisfy redressability through other mechanisms such as bounties or attorney's fees poses a more difficult question. With respect to attorney's fees, ${ }^{140}$ the Supreme Court in Diamond v. Charles ${ }^{141}$ found that a party's interest in attorney's fees was insufficient to support standing. Even though Diamond stood to lose fees if the case were dismissed, he lacked standing to continue

137. Punitive damages rarely if ever have been authorized or awarded in contexts such as declaratory judgment actions to deter conduct before the injury occurs, presumably because the "punishment" is not yet due. No Article III obstacle, however precludes such use as long as a sufficient risk of continuing injury exists, as in Laidlaw. With respect to deterring future harm, the punitive damages function similarly to an award of civil penalties.

138. 435 U.S. 247 (1978).

139. Id. at 266.

140. See Evans v. Jeff D., 475 U.S. 717, 730 (1986) (holding that an award of attorney's fees belongs to a party and not to the attorney).

141. 476 U.S. 54 (1986). 
litigating the merits. Rather, what is required is "an injury with a nexus to the substantive character of the statute or regulation at issue." ${ }^{142}$ A party's expectation of an attorney's fee award does not confer standing or demonstrate redressability because it is not directly related "to the substantive character of the statute or regulation at issue." ${ }^{143}$ Otherwise, Congress could avoid standing (and advisory opinion) obstacles merely by dint of affording anyone ten percent reimbursement of fees for any successful constitutional claim against the government. The injury in fact and redressability prongs would be circumvented. The expectation of an attorney fee award therefore does not give rise to standing-at least under current doctrine-if no other injury exists.

Similarly, in Steel Company the Court held that the expectation of reimbursement for litigation costs is insufficient to satisfy redressability. ${ }^{144}$ Even though Congress had created the expectation, only interests related to the substance of the cause of action suffice to create standing. As the Court explained, "[t]he litigation must give the plaintiff some other benefit besides reimbursement of costs that are a byproduct of the litigation itself." ${ }^{145}$ Reimbursement of litigation expenses would not redress the underlying wrong.

Some have argued that bounties operate quite differently. ${ }^{146}$ If Congress provided that successful plaintiffs in citizen suits receive a cash bounty, the argument goes, then redressability concerns are satisfied. The bounty might redress the injury in one of two ways: first, it might compensate for some of the environmental or other loss suffered; and second, it might redress the procedural interest-the bounty-conferred by Congress on citizens wishing to challenge administrative action.

Support for this view stems from historical qui tam practice. Qui tam and informer's actions have proceeded since the nation's founding. ${ }^{147}$ There, the injury can be conceptualized either as derivative, e.g., suing on behalf of the United States, or more individuated in the sense of efforts to take advantage of the opportunity provided by

142. See id. at 70.

143. See id.

144. See Steel Co. v. Citizens for a Better Env't, 523 U.S. 83, 107-108 (1998).

145. Id.

146. See Sunstein, supra note 15 , at 232.

147. See generally Evan Caminker, The Constitutionality of Qui Tam Actions, 99 YALE L.J. 341 (1989); Harold J. Krent, Executive Control Over Criminal Law Enforcement: Some Lessons From History, 38 AM. U. L. REV. 275 (1989). 
Congress to collect funds. The prospect of a bounty affords a personal stake in the controversy. Under either view, the payment of the bounty redresses the injury. As even the plurality opinion in Lujan noted, "[n]or, finally, is [this] the unusual case in which Congress has created a concrete, private interest in the outcome of a suit against a private party for the government's benefit, by providing a cash bounty for the victorious plaintiff." ${ }^{148}$ Several courts recently have upheld standing in qui tam cases on the ground that the bounty provides sufficient interest to confer standing. ${ }^{149}$

Indeed, prior to enactment of citizen-suit provisions in the Clean Water Act, individuals attempted, albeit unsuccessfully, to prevent violation of environmental laws through qui tam suits. ${ }^{150}$ Like citizen suits, qui tam actions provide a means through which citizens can help enforce the laws even when the executive branch has not taken an active enforcement role.

However, the Supreme Court's decision in Vermont Agency of Natural Resources $v$. United States ex rel. Stevens ${ }^{151}$-decided in the same term as Laidlaw-rejected the bounty theory. Before concluding that a private party could not bring a qui tam action against a state, the Court considered whether the qui tam relator had standing to pursue the False Claims Act case against Vermont. Although the relator, if successful, would have collected a bounty, "the same might be said of someone who has placed a wager upon the outcome. An interest unrelated to injury in fact is insufficient to give a plaintiff standing." 152 A bounty does not alter the nature of the injuries to be redressed in litigation, but only creates a stake in its outcome, much like an attorney hoping for a contingency fee or fee shifting award might enjoy.

A comparison with the letters of marque cases is helpful. There, Congress in a sense creates standing, but before any party can invoke

148. Lujan v. Defenders of Wildlife, 504 U.S. 555, 572-73 (1992).

149. See United States ex rel. Kreindler \& Kreindler v. United Techs., 985 F.2d 1148, 1154 (2d Cir. 1993) ("Because the qui tam relator (1) funds the prosecution of the FCA suit, (2) will receive a private share in the government's recovery only upon prevailing, (3) may be liable for costs ... the relator's personal stake in the case is sufficiently ensured."); see also United States ex rel. Truong v. Northrop Corp., 728 F. Supp. 615, 618-19 (C.D. Cal. 1989).

150. See Connection Action Now, Inc. v. Roberts Plating Co., 457 F.2d 81, 88 (2d Cir. 1972) (explaining in part that private suits "could well be highly disruptive to permit intervention in Refuse Act enforcement by a private citizen not charged with general responsibility or oversight").

151. 120 S. Ct. $1858(2000)$.

152. Id. at 1862. 
the court's jurisdiction, that party must first take action by capturing the foreign ship and towing it back into this country's territory. The private party must obtain the property interest in advance of the lawsuit-the lawsuit by itself does not create the interest that gives rise to standing. The cognizable injury must be distinct from the lawsuit.

Viewed another way, the Court does not recognize property interests in litigation as sufficient to support standing. Otherwise, Congress could delegate the responsibility to enforce laws through litigation to any concerned individual, irrespective of the individual's interest in the litigation. Although the line between creation of interests antecedent to the litigation and in the litigation itself may seem thin, it represents one way for the Court to protect against widespread delegation of the President's authority to enforce the law. ${ }^{153}$ Just as injuries in fact must be individuated under Lujan, so too must remedial mechanisms be linked to specific injuries. And, courts in other contexts have held that an interest in avoiding or carrying out litigation is not sufficient to keep lawsuits alive. ${ }^{154}$ The individual injury requirement safeguards against congressional displacement of the President as the chief law enforcement officer.

Bounties, nonetheless, can create sufficient redressability if a separate injury in fact exists. In that case, the bounty may serve the same deterrent function as civil penalties. If the injury may continue after the lawsuit, then the bounty deters future wrongdoing. Like the civil penalties in Laidlaw, bounties can act as a financial deterrent of unlawful conduct.

Congress thus has ample discretion to ensure redressability, both by crafting findings that demonstrate the link between the asserted injury and the relief sought, and by authorizing remedies such as punitive damages, civil penalties, and even at times bounties that serve a deterrent function. As long as a sufficient chance of future injury exists, creative remedial schemes satisfy Article III's mandate of a redressable injury.

\section{CONCLUSION}

Laidlaw suggests a new role for Congress in linking remedies to injuries. Congress's policymaking authority plainly includes the power to authorize individuals who have been injured to sue to pre-

153. See Krent \& Shenkman, supra note 14 at 1801-40.

154. See Diamond v. Charles, 476 U.S. 54 (1986); see also FTC v. Standard Oil Co., 449 U.S. 232 (1980) (litigation costs are at times "part of the social burden of living under government"). 
vent recurrence of statutory and constitutional violations that may affect them. Judges should defer to congressional determinations and findings that particular injuries will redress particular harms. Congress has greater ability to assess social, economic, and technological trends that underlie the inquiry whether injury is likely to recur and whether a remedy is likely to deter the unlawful conduct. At the same time, encouraging such findings facilitates deliberation within Congress, and the findings enhance the transparency of legislative action. Congress should only open the courthouse doors when the interests raised are clear, and the benefits sought from the lawsuit are tangible.

Courts, however, continue to discharge a critical function by requiring each plaintiff to demonstrate redressability. To the extent that the redressability requirement stems from the case or controversy limitation in Article III, redressability ensures adverseness, limits the role of ideological plaintiffs, and prevents courts from needlessly resolving disputes that might embroil them in controversy with the more politicized branches. Review of congressional findings of redressability is needed because the findings may be implausible, or they might not be probative in the context of the facts of a specific case. Moreover, review is also critical to ensure that congressional mechanisms designed to further access to courts-creation of property interests, damage remedies, and bounties-build on interests separate from those in the lawsuit itself. Otherwise, Congress can delegate to private parties an enforcement role at odds with Article II's mandate of presidential control over law enforcement.

Nonetheless, with limited exceptions, Congress properly enjoys wide latitude in determining which remedies are appropriate to vindicate which interests. By restoring Congress to its appropriate role, Laidlaw redresses the Court's law of redressability. 
Heinonline -- 12 Duke Envtl. L. \& Pol'y F. 118 2001-2002 